Article

\title{
New Perspectives on the Community Impact of Rural Education Deserts
}

\author{
Paige N. Park ${ }^{1}\left(\mathbb{D}\right.$, Scott R. Sanders ${ }^{2, *}$, Michael R. Cope ${ }^{2} \mathbb{D}$, Kayci A. Muirbrook ${ }^{2}$ and Carol Ward $^{2} \mathbb{D}$ \\ 1 Department of Demography, University of California, Berkeley, CA 94720, USA; paige_park@berkeley.edu \\ 2 Department of Sociology, Brigham Young University, Provo, UT 84602, USA; michaelrcope@byu.edu (M.R.C.); \\ kmuirbro@byu.edu (K.A.M.); carol_ward@byu.edu (C.W.) \\ * Correspondence: scott_sanders@byu.edu
}

check for updates

Citation: Park, P.N.; Sanders, S.R.; Cope, M.R.; Muirbrook, K.A.; Ward, C. New Perspectives on the Community Impact of Rural Education Deserts. Sustainability 2021, 13, 12124. https://doi.org/10.3390/ su132112124

\section{Academic Editors:}

Chrysanthi Charatsari and Evagelos D. Lioutas

Received: 23 August 2021

Accepted: 21 October 2021

Published: 3 November 2021

Publisher's Note: MDPI stays neutral with regard to jurisdictional claims in published maps and institutional affiliations.

Copyright: (C) 2021 by the authors. Licensee MDPI, Basel, Switzerland. This article is an open access article distributed under the terms and conditions of the Creative Commons Attribution (CC BY) license (https:/ / creativecommons.org/licenses/by/ $4.0 /)$.

\begin{abstract}
Understanding how the lack of higher education opportunities due to geographic distance affects perceptions of communities and education is essential in creating sustainable education systems in rural areas. More specifically, this research examines how geographic distance and the absence of institutes, sometimes called an education desert, affect perceptions of community and the perceived value of education. We used data from the 2017 Rural Utah Community Study (RUCS) of residents living in twenty-five rural communities, with a sample size of 1286 , and found that the proximity to different types of higher education, four- and two-year institutions, can significantly influence community well-being and the perceived value of education.
\end{abstract}

Keywords: education desert; higher education; rural; community satisfaction

\section{Introduction}

In 2018, a report by the Urban Institute [1] highlighted the effect that geographical distance from institutes of higher learning has on enrollment and completion of postsecondary degrees in the United States. Because the number of universities and colleges are limited, sometimes rural residents must travel great distances to continue their education after high school. This distance creates what the authors call "education deserts", the effects of which are especially felt by rural residents in the western United States. Additional research on western rural communities indicates that limited access to higher education, i.e., living in an education desert, is a significant factor in community satisfaction [2]. Building on this research, we address how different types of higher education deserts, including two-year colleges, four-year colleges' satellite campuses, and four-year colleges, affect community satisfaction [3], and the perceived value of education in rural areas. Based on theories where geographic distance is a barrier to education, we hypothesize that the limitation of living in an education desert will have negative effects on the perceived value of education and community satisfaction. By understanding the association between access to education and community satisfaction, this research elucidates the role that institutes of higher education play in sustaining rural, and often at-risk, communities. This link between higher education and community well-being is an understudied but an essential component of a sustainable education system in rural communities.

In the US education system, most students continue to a four-year university for a bachelor's degree, or a two-year community college for an associate's degree and then ideally transfer to a four-year university to complete a bachelor's degree. However, current research on rurality and higher education suggests that four-year universities often fail to provide rural students with knowledge or skills that would help them remain in their community, while two-year schools can better contextualize education to the rural setting [4]. For instance, some smaller, rural-serving colleges in Utah have focused on educating rural residents about the practical, more contextualized skills associated with sustainability in farming, ranching, and community building [5], while Utah's four-year universities tend to 
emphasize urban sustainability and prepare students for careers in "research, management, consulting medicine, and related fields," many of which require emigrating from rural areas to pursue [6,7]. Therefore, we hypothesized that living near two-year schools and satellite campuses would have a positive relationship with residents' community satisfaction, while proximity to four-year colleges would have a negative relationship with community satisfaction.

Using data from the 2017 Rural Utah Community Study (RUCS) of residents living in twenty-five rural communities - i.e., communities with populations of 2500 to 5000 —and by geo-referencing their location to measure the geographic traveling distance from higher education institutions, this study identifies respondents living in higher education deserts. We then address the issue of community satisfaction/attachment, the respondents' demographic characteristics, and their opinions about education to examine the relationships, if any, between community satisfaction, perceptions of education, and geographic distance to post-secondary institutions.

\subsection{Rural Participation in Higher Education}

The extant research largely supports the claim that residents in rural communities are disadvantaged by poor access to and participation in higher education [8-13]. Most of the studies focused on young people living in rural areas and their decisions about furthering their education. Feeling the pull of opportunities that beckon from outside small towns, many young rural residents believe that they must out-migrate to continue their education and get a good job [14-17]. While moving away from home is a generally accepted fact of rural life [18], decisions to do so are seldom easy. Many young people struggle with conflicting choices, with higher education and better opportunities pulling in one direction and social bonds and community attachments tugging in another [15,17]. This lack of locally accessed education can be thought of as living in an education desert. Furthermore, the term education desert highlights that geographic barriers are requiring rural residents to travel significant distances to access higher education.

For rural residents living in an education desert, the choice to stay or leave is difficult, there are several other factors beyond the student's control to consider. These include low socioeconomic status, perceived lack of preparedness, ineffective teachers, lack of awareness of post-secondary options, race/ethnicity, lack of social capital, and, most importantly for this study, distance from higher education institutions $[8,9,11,12,19,20]$. Conversely, factors that improve the chance of going to college include parental academic attainment, the student's achievement in school, social assets, financial resources, having two parents at home, and clear parental and teacher expectations $[9,19,20]$. While social influences can have a significant positive impact on educational aspirations, they may also have a negative influence in rural areas [21].

Apart from the decision to pursue post-secondary education, rural youth must consider the type of institution to attend. According to Byun et al. [22], 65\% of rural students who receive post-secondary schooling attend a two-year college at some point and many "may take advantage of community college systems either initially or somewhere along their educational trajectory" (p. 831). Indeed, rural youth are less likely than urban youth to apply to prestigious four-year colleges [11] and their educational trajectories may differ within the rural community itself due to social class, educational ambition, and parental guidance [23].

Rural students, when compared to urban counterparts, face additional obstacles to higher education. According to Jukkala et al. [24], rural medical professionals who seek further education often encounter specific barriers to their educational goals, including limited access to desired schools and professional isolation. Some rural professionals report that many programs "are designed to meet the needs of urban and suburban health care professionals and may not meet the needs of rural providers" [24] (p. 561). 


\subsection{Distance as a Barrier: Education Deserts}

Nationwide, two out of every three undergraduate students attend college within 25 miles of their home communities, which indicates that place matters for higher education choices [25]. This is particularly pertinent for rural communities, where a significant determinant for higher education choice is the community's distance from the college. As mentioned earlier, the literature calls these areas "education deserts" - that is, communities with only one public broad-access community college nearby—or none [26]. Recent figures estimate that $82 \%$ of people in education deserts live in rural areas, which amounts to as many as 41 million people living some distance from a college or university [27]. This institutional scarcity in rural areas relates not only to college choice but also to whether students attend college at all. Indeed, many rural students, understandably anxious about leaving home [12], are less likely to apply to college if there are few schools nearby [25,28]. Furthermore, students living in education deserts generally have lower levels of educational attainment [26,29], which influences their choice of institution.

Although some studies say that compared to factors such as socioeconomic status $[10,13]$, distance from university is only a moderately important influence on ru$\mathrm{ral} /$ urban educational inequality, more recent representative data suggest that rurality may be a moderating variable that limits the already disadvantaged $[8,11,26,29]$. Rurality decreases the effect of variables that typically have a positive relationship with higher education achievement; that is, even among higher SES students, rural youth living far from universities remain educationally disadvantaged compared to urban students [11].

While the research overall shows that living in education deserts limits higher education opportunities, the influence of distance on residents' perceptions of their communities is less clear. For this reason, this study considers how community satisfaction levels vary between towns in education deserts and those with higher education opportunities nearby.

\subsection{Community Satisfaction}

Community satisfaction refers to the subjective evaluation of local conditions and their contribution to the quality of life [30,31]. In rural communities, as elsewhere, a variety of conditions or services such as social networks, medical/health care services, commercial amenities, and public education affect community satisfaction [32-35]. Individual-level variables such as income, age, gender, and how long someone has lived in the community, as well as place-based indicators such as population size and distance from other communities, can affect community satisfaction [36].

Although previous research investigated how perceptions of local public education and distance from urban centers influence community satisfaction, there is a lack of understanding of how perceptions of the importance of college, or distance from various types of higher education affect community satisfaction. Several studies have analyzed the link between educational perceptions on community satisfaction; however, they primarily focused on evaluations of K-12 education, and then with mixed results [33,35]. Other studies found that perceptions of public schools are central to predicting community satisfaction [33,37]. Still, others say that this is not as critical as perceptions of medical or commercial services [35]. Even so, a recent study that investigated rural satisfaction with education opportunities found that rural residents in the western United States are most dissatisfied with limited higher education opportunities and a lack of jobs for high school graduates [2]. Furthermore, the study did not analyze perceptions of community by distance from specific types of higher education - that is, two-year vs. four-year institutions.

\subsection{Policy Considerations}

Although policies implemented in rural communities in other countries have improved educational access for rural youth [38,39], it is unclear how similar problems in the U.S. might be remedied. Corbett and Forsey [15] argue that the neoliberal concept of education may not be suited to rural community living in the U.S. Moreover, mixed mes- 
sages about life outside rural communities can complicate matters, and while rural youth may feel pressured to seek a post-secondary education beyond their communities, leaving home brings challenges of its own. Some students, especially if they plan to return home, may wonder if a higher education is worth their time and money [14,40]. Nevertheless, Kim [27] argues that decreasing education deserts by providing more opportunities for local higher education will benefit rural areas by reducing out-migration, lowering tuition costs, and increasing local employment.

Corbett [4] similarly argues that current forms of rural education typically result in siphoning youth from the community or standardizing schooling in ways that remove it from the contexts-the places and spaces-in which it is situated. From this perspective, de-contextualized rural schooling simply prepares secondary school students to leave for an education that they may not use once they return to their home communities. Corbett [4] maintains that this need not be the case and that better education policies can help rural communities to thrive. He believes that pursuing higher education would be less threatening to rural students, their families, and the community if there were more higher education institutions within easy reach. Localized higher education opportunities could focus on nurturing rural community priorities rather than supporting neoliberal metro-centric forms of schooling that do not help those who want to live and work in rural communities.

\subsection{Current Study}

Because of a scarcity of research on the relationship between types of higher education, perceptions of their importance, and community satisfaction, this study examines how these concepts may be related. Utah is a good setting to explore this issue because a significant proportion of its population lives in 'education deserts' [41]. Furthermore, the state has implemented policies to provide better opportunities for rural students [42], by establishing satellite campuses to provide better access to higher education to rural communities. In addition, a rural two-year college is located near many of the communities in this study. Furthermore, this college, based on the Chronicle of Higher Education rankings [43], is among the best two-year colleges in the U.S. offering primarily associate degrees. Indeed, for this study, the college's various enrollment options render it a valuable test case for how proximity to smaller or satellite institutions affects community satisfaction compared with traditional four-year schools.

We predict that residents who live close to public four-year universities or smaller two-year colleges providing appropriate courses for rural communities will have higher levels of satisfaction than residents living some distance away. Additionally, following Corbett [4], we expect that residents in communities closer to small local colleges-typically two-year schools-will have higher levels of satisfaction or attachment than those living within the range of a four-year university, due to the more contextualized and affordable opportunities smaller institutions offer. If true, this would suggest that local education systems have a positive effect on the rural community experience and that policymakers should recognize and try to mitigate the disadvantages of education deserts.

\section{Materials and Methods}

\subsection{Data}

The data for this research come from the 2017 Rural Utah Community Study (RUCS), which randomly distributed a survey to 25 rural towns (populations of 2500 to 5000) in Utah that year. We used the Dillman method for mailed surveys in the sampling process [44] - that is, a few days before the questionnaire arrived, we sent a letter to respondents about the incoming survey packet. Later, we sent the survey packet, which included a cover letter, pre-paid return envelope, a 16-page survey, and a \$2 remuneration. Data collection yielded a sample size of 1286 , with an overall adjusted response rate was about $63 \%$. Survey items included questions about community experience, attitudes towards education, and demographics. 


\subsection{Measures}

For this study, community satisfaction serves as the primary variable of interest. We created the community satisfaction measure using a well-established two-item index of rural communities [31,45,46]. Question 1-“How satisfied are you living in your community?"- drew responses ranging from 1 (dissatisfied) to 7 (satisfied). Question 2"Imagine an ideal community where you would like to live. Where would you rank your present community compared with your ideal community?"- drew responses ranging from 1 (worst) to 7 (best). The alpha reliability for the satisfaction index is good at 0.848 The scale is calculated as the mean of the scores on the two separate variables.

The primary independent variables were, first, distance variables indicating whether a town was within 35 miles of (1) a four-year university or (2) a two-year college or satellite campus of a four-year university and, second, the respondents' perceived value of a high school and college education. We combined the two-year schools and satellite campuses into a single variable to capture institutions that cater to rural areas by offering more contextualized degree options, which both the satellite and two-year colleges do. The variable indicating whether a community is close to a four-year university is an indicator variable, where $1=$ towns within 35 miles of a four-year university and $0=$ towns farther than 35 miles from a four-year university. The variable describing whether a community is within range of a two-year college or satellite campus is an indicator variable, where $1=$ towns within 35 miles of a two-year college or a satellite campus and $0=$ towns farther than 35 miles from a two-year college or satellite campus. The two items related to high school and college importance asked respondents about how important graduating from (1) high school and (2) college is to succeed in their community. Response options ranged from 1 (not at all) to 7 (extremely).

Control variables include a series of education-related measures as well as demographic variables. The three education measures include the respondent's education level, the education level of the respondent's father, and the education level of the respondent's mother, each measured on a 1 to 7 scale where $1=11$ th grade or less, $2=$ high school or equivalent-General Education Development (GED), 3 = one year of college or trade school, $4=$ two years of college or trade school, $5=$ three years of college or trade school, $6=$ four years of college or BS/BA degree, and $7=$ graduate degree.

Other demographic variables are included as controls. We created the length of residence variable by dividing the number of years lived in the community by the respondent's age. This variable indicates the proportion of the respondent's life spent in the community rather than the number of years of residence. Additionally, biological sex ( $1=$ male), age, income, marital status ( $1=$ unmarried), number of children living in the home, and employment status $(1=$ employed $)$ were included as controls. Finally, we added two measures of satisfaction with community amenities to the models, which capture the respondents' perceptions of (1) shopping and (2) restaurants in the community on a scale from 1 (badly needs improvement) to 7 (exceptional). Finally, to address missing data means substitution was used for the income, paternal education, shopping, and restaurants variables. Any remaining respondents with missing data were dropped from our analyses using listwise deletion, resulting in an analytic sample size of 1018. See Table 1 for descriptive statistics of all variables included in the analysis. 
Table 1. Descriptive data of key variables (Rural Utah Community Study).

\begin{tabular}{|c|c|c|}
\hline Variables & Mean/Percent & SD \\
\hline Community Satisfaction & 5.366 & 1.327 \\
\hline \multicolumn{3}{|l|}{ Within $35 \mathrm{mi}$ of four-year college } \\
\hline Yes & $17.85 \%$ & \\
\hline No & $82.15 \%$ & \\
\hline \multicolumn{3}{|l|}{ Within $35 \mathrm{mi}$ of two-year college or satellite } \\
\hline Yes & $54.11 \%$ & \\
\hline No & $45.89 \%$ & \\
\hline \multicolumn{3}{|l|}{ Education } \\
\hline 11th grade or less & $1.90 \%$ & \\
\hline High school or General Education Development (GED) & $18.95 \%$ & \\
\hline One year of college or trade school & $17.47 \%$ & \\
\hline Two years of college or trade school & $17.05 \%$ & \\
\hline Three years of college or trade school & $5.63 \%$ & \\
\hline Four years of college or BS/BA degree & $28.00 \%$ & \\
\hline Graduate degree & $10.99 \%$ & \\
\hline \multicolumn{3}{|l|}{ Father's Education } \\
\hline 11th grade or less & $14.50 \%$ & \\
\hline High school or General Education Development (GED) & $35.61 \%$ & \\
\hline One year of college or trade school & $10.95 \%$ & \\
\hline Two years of college or trade school & $11.76 \%$ & \\
\hline Three years of college or trade school & $3.76 \%$ & \\
\hline Four years of college or BS/BA degree & $16.03 \%$ & \\
\hline Graduate degree & $7.38 \%$ & \\
\hline \multicolumn{3}{|l|}{ Mother's Education } \\
\hline 11th grade or less & $11.22 \%$ & \\
\hline High school or General Education Development (GED) & $40.91 \%$ & \\
\hline One year of college or trade school & $12.47 \%$ & \\
\hline Two years of college or trade school & $13.96 \%$ & \\
\hline Three years of college or trade school & $2.66 \%$ & \\
\hline Four years of college or BS/BA degree & $15.65 \%$ & \\
\hline Graduate degree & $3.13 \%$ & \\
\hline Importance of High School & 6.450 & 1.045 \\
\hline Importance of College & 5.336 & 1.490 \\
\hline Length of Residence & 0.4949 & 0.343 \\
\hline \multicolumn{3}{|l|}{ Gender } \\
\hline Male & $48.85 \%$ & \\
\hline Female & $51.15 \%$ & \\
\hline Age & 53.605 & 16.282 \\
\hline \multicolumn{3}{|l|}{ Income } \\
\hline$\$ 1$ to $\$ 10,000$ & $2.59 \%$ & \\
\hline$\$ 10,000$ to $\$ 20,000$ & $14.37 \%$ & \\
\hline$\$ 20,000$ to $\$ 30,000$ & $7.05 \%$ & \\
\hline$\$ 30,000$ to $\$ 40,000$ & $10.60 \%$ & \\
\hline$\$ 40,000$ to $\$ 50,000$ & $7.72 \%$ & \\
\hline$\$ 50,000$ to $\$ 60,000$ & $11.10 \%$ & \\
\hline$\$ 60,000$ to $\$ 70,000$ & $14.05 \%$ & \\
\hline$\$ 70,000$ to $\$ 80,000$ & $8.40 \%$ & \\
\hline$\$ 80,000$ to $\$ 90,000$ & $8.15 \%$ & \\
\hline$\$ 90,000$ to $\$ 100,000$ & $4.37 \%$ & \\
\hline$\$ 100,000$ to $\$ 150,000$ & $6.86 \%$ & \\
\hline over $\$ 150,000$ & $4.75 \%$ & \\
\hline \multicolumn{3}{|l|}{ Marital Status } \\
\hline Married & $80.61 \%$ & \\
\hline Unmarried & $19.39 \%$ & \\
\hline
\end{tabular}


Table 1. Cont.

\begin{tabular}{|c|c|c|}
\hline Variables & Mean/Percent & SD \\
\hline Children at Home & 1.131 & 1.602 \\
\hline \multicolumn{3}{|l|}{ Employment } \\
\hline Full-Time & $48.06 \%$ & \\
\hline Part-Time & $14.08 \%$ & \\
\hline Unemployed & $3.82 \%$ & \\
\hline Not in Workforce & $34.05 \%$ & \\
\hline Shopping Amenities & 2.991 & 1.486 \\
\hline Restaurant Amenities & 3.170 & 1.725 \\
\hline
\end{tabular}

\subsection{Analytic Strategy}

To address each research question, we ran two OLS regression models that include all independent variables and control variables. The only difference between the models is that the first excludes commercial amenities variables while the second includes them. We did this to understand how distance from two-year or four-year schools might relate to amenities. For example, if distance variables become non-significant after adding in the amenities variables, we might better account for their supposed influence on community satisfaction by their distance, near or far, from the amenities in towns with higher education options. We used data weights in the regression analysis to account for disproportionate response rates among certain population demographics. To reflect more accurately the population of each town, we weighted the models by age and sex.

\section{Results}

Our results show that while perceptions of education and distance from educational institutions matter for community satisfaction, perceptions and distance from different types of education have different effects. Valuing high school matters for community satisfaction, while valuing college does not. Similarly, living near a four-year university improves community satisfaction, while living near a two-year school has no impact.

Table 2 shows the results from the OLS regression models. Model 1 excludes commercial amenities; Model 2 includes them. Examined with and without the amenities variables, only high school importance shows a significant relationship with community satisfaction (Model 1: $\mathrm{b}=0.291, p<0.001$; Model 2: $\mathrm{b}=0.272, p<0.001$ ). The strength of the relationship between high school importance and community satisfaction and the null relationship with college importance suggests that their communities likely meet the educational needs of those who value high school and hence feel more satisfied there. On the other hand, perceptions of the importance of a college education do not affect community satisfaction in the same way, which calls for further investigation into the relationship between community satisfaction and higher education.

Table 2 also includes the distance from higher education variables, separated into the distance from four-year and two-year institutions. When amenities are excluded, both four-year and two-year institutions in Model 1 are significantly related to community satisfaction, though in opposite directions. While proximity to a four-year school has a positive relationship with community satisfaction $(b=0.424, p<0.01)$, proximity to a two-year school has a negative relationship $(b=-0.296, p<0.01)$. However, when amenities variables are added, only the relationship between satisfaction and four-year schools remains $(b=0.362, p<0.01)$. This indicates that the proximity of a four-year institution and its effect on the community experience differs significantly from and is better than the effect of proximity to a two-year institution. 
Table 2. Community Satisfaction, Distance to Education, and Importance of Education.

\begin{tabular}{|c|c|c|c|c|c|c|}
\hline & \multicolumn{3}{|c|}{ Model 1} & \multicolumn{3}{|c|}{ Model 2} \\
\hline & Coef. & SE & $p$ & Coef. & SE & $p$ \\
\hline $\begin{array}{l}\text { Distance from four-year } \\
\text { Institutions }\end{array}$ & 0.424 & 0.135 & 0.002 & 0.362 & 0.124 & 0.004 \\
\hline $\begin{array}{l}\text { Distance from two-year } \\
\text { Institutions }\end{array}$ & -0.296 & 0.103 & 0.004 & -0.136 & 0.097 & 0.163 \\
\hline Education Attained & 0.077 & 0.032 & 0.016 & 0.071 & 0.029 & 0.014 \\
\hline Father's Education & 0.062 & 0.033 & 0.060 & 0.047 & 0.030 & 0.124 \\
\hline Mother's Education & -0.046 & 0.038 & 0.218 & -0.032 & 0.034 & 0.346 \\
\hline Importance of High School & 0.291 & 0.058 & 0.000 & 0.272 & 0.054 & 0.000 \\
\hline Importance of College & -0.063 & 0.041 & 0.125 & -0.059 & 0.037 & 0.114 \\
\hline Length of Residence & 0.190 & 0.153 & 0.215 & 0.173 & 0.140 & 0.214 \\
\hline Male & 0.095 & 0.106 & 0.374 & 0.071 & 0.097 & 0.462 \\
\hline Age & 0.012 & 0.004 & 0.007 & 0.009 & 0.004 & 0.024 \\
\hline Income & 0.012 & 0.015 & 0.407 & 0.011 & 0.013 & 0.429 \\
\hline Unmarried & -0.333 & 0.138 & 0.016 & -0.174 & 0.127 & 0.170 \\
\hline Children at Home & 0.077 & 0.038 & 0.045 & 0.054 & 0.035 & 0.125 \\
\hline \multicolumn{7}{|l|}{ Employment } \\
\hline Part-Time & -0.031 & 0.160 & 0.845 & -0.011 & 0.146 & 0.941 \\
\hline Unemployed & -0.208 & 0.282 & 0.459 & -0.257 & 0.257 & 0.318 \\
\hline Not in Workforce & 0.045 & 0.139 & 0.746 & 0.056 & 0.126 & 0.655 \\
\hline Shopping Amenities & & & & 0.244 & 0.038 & 0.000 \\
\hline Restaurant Amenities & & & & 0.133 & 0.033 & 0.000 \\
\hline Constant & 2.596 & 0.463 & 0.000 & 1.685 & 0.432 & 0.000 \\
\hline$R^{2}$ & 0.1418 & & & 0.2891 & & \\
\hline Adj. $R^{2}$ & 0.1203 & & & 0.2688 & & \\
\hline$F$ & 6.21 & & & 13.53 & & \\
\hline$p$ & 0.0000 & & & 0.0000 & & \\
\hline
\end{tabular}

\section{Discussion}

As the present U.S. administration drafts plans for free tuition at community colleges and COVID-19 shifts educational norms, questions about how different types of education (in-person vs. online, two-year vs. four-year) might impact the community experience are increasingly relevant $[47,48]$. This study addresses how perceptions of education and distance from higher education institutions influence community satisfaction. Our findings highlight the disparate effects of perceptions of the importance of high school and the importance of college on community satisfaction and the different effects of living close to a four-year versus a two-year institution.

While those who value high school are typically more satisfied with their communities, those who value college are not. It is unclear why the positive relationship between the importance of high school and satisfaction exists, but it may be that those who value high school feel that a high school degree is necessary for entry into the local labor market and therefore worth the investment, whereas the benefits from some college or a college degree are not apparent in their communities. That is, those who return on to their communities with college training are not finding the financial and professional benefits they believed are associated with attending college. This lack of professional and financial opportunities for those with college education results in lower perceived value in college education in these communities.

Many of the two-year colleges and satellite campuses in Utah attempt to bridge the gap between four-year universities and high schools by offering more rural-relevant and proximate higher education options. For example, many two-year programs offer more practical advice about sustainable farming/ranching and sustainability in rural communities, while the sustainability courses and programs offered at four-year universities are more research driven and policy focused. This might suggest that those who live near two-year campuses might feel more satisfied in their communities than those near four-year 
universities because they have greater access to educational resources that teach about sustainability (among other topics) in ways that are easily transferable to their lives, should they choose to stay in their community long term.

Surprisingly, we found that the opposite was true; the distance from university does matter for community satisfaction, but four-year institutions only. While students living close to four-year schools report higher satisfaction levels, those living close to two-year colleges report lower satisfaction levels. In other words, two-year community colleges and satellite campuses do not improve community satisfaction, whereas four-year schools do. These findings challenge the idea that proximity to local two-year educational institutions might lead to a higher valuation of college and increased community satisfaction. Indeed, our results show that neither of these outcomes occurs. Significantly, we also find that proximity to four-year schools can positively affect community satisfaction, which challenges Corbett's assessment that large four-year institutions may not influence rural communities in positive ways because of their decontextualized educational opportunities. The present research suggests that four-year colleges are doing a better job than two-year schools at improving community satisfaction.

This finding is important for those considering expanding two-year college access to improve nearby community life. Our findings suggest that some rural residents are faced with the decision to stay in the communities with a low return on their two-year college education or leave their community for larger labor markets and community to four-year colleges. As a result, for some rural residents, proximity to a two-year college can be an expensive way to delay the decision to leave a rural community. Thus, the U.S. government's focus on community college access and expansion may have to weigh what four-year universities have that two-year colleges lack. Regardless, whatever other benefits two-year colleges may bring, these schools do not positively influence nearby communities the same way four-year schools do.

While this research provides important insights into education deserts and rural communities, this research has some limitations. First, the data were collected before the COVID-19 pandemic. While the pandemic was disruptive to schools and communities in 2020, online education did not last. This is particularly the case in Utah where the Commissioner of Higher Education reported little lasting effect on the in-person enrollment of Utah universities and colleges [49]. This suggests that the education deserts addressed in this study persisted. However, additional research is needed to understand the longterm effects of COVID-19 more fully. Another limitation of this paper is that these rural communities are demographically relatively homogeneous. Utah is overwhelmingly White, and the data used in this study do not provide insights into the challenges, and perhaps intersectionality, of being a racial minority and living in an education desert. Additional research into the challenges of ethnic and racial minority groups, in particular Indigenous nations, is needed to ensure any unique needs for these populations are being met.

\section{Conclusions}

In conclusion, we echo Farrington and Farrington [50], who argue that "greater social justice cannot be achieved without greater social inclusion, which requires that people have access to a range of activities regarded as typical of their society; greater social inclusion requires greater accessibility" (p. 2). While sentiments such as these have spurred movements for greater access to education, often in the form of two-year colleges or satellite campuses close to rural communities, the present study suggests that access to these schools may not improve community life in the same way or as significantly as four-year schools do. However, four-year universities often require rural residence to leave their home communities to access education. Furthermore, there is often a labor market mismatch, where the jobs available in rural communities are often limited to education and health care. This limits the perceived value of university education for some rural residents and can contribute to the decline in the perceived value of an education as well as measures of community satisfaction. 
Perhaps future researchers can explore the specific factors associated with four-year universities that influence community satisfaction and the reasons for and implications of the relationship between the valuation of education and the rural community experience. Emerging research on the effectiveness of online education established in the COVID19 pandemic could be a key to eliminating some of the penalties associated with living in an education desert. Furthermore, the rise of online work opportunities might allow more service sector jobs to be completed by workers in rural communities. However, the full effects of these swifts are still being played out by corporations, universities, and communities. Continued research on education deserts and their impact on communities is needed to fully understand how to help many rural communities throughout the western United States.

Author Contributions: Conceptualization, S.R.S. and C.W.; methodology, P.N.P. and K.A.M.; formal analysis, P.N.P.; investigation, P.N.P.; resources, data curation, M.R.C. and S.R.S.; writing-original draft preparation, P.N.P. and K.A.M.; writing—review and editing, S.R.S., M.R.C., and C.W. All authors have read and agreed to the published version of the manuscript.

Funding: The authors disclosed receipt of the following financial support for the research, authorship, and/or publication of this article: Data collection efforts were funded in part by two sources internal to Brigham Young University: The Charles Redd Center for Western Studies, and the College of Family, Home, and Social Sciences.

Institutional Review Board Statement: This study was conducted according to the guidelines of the Declaration of Helsinki, and approved by the Institutional Review Board of Brigham Young University (protocol code: E16349 approved on 15 September 2015).

Informed Consent Statement: All persons gave their informed consent prior to their inclusion in this study.

Data Availability Statement: The datasets generated during and/or analyzed during the current study are available from the corresponding author on reasonable request. The data are not publicly available due to the inclusion of information that could compromise the privacy of the research participants.

Acknowledgments: The authors thank Jorden E. Jackson and the students in BYU Communities Studies Lab for help during the data collection and curation phases of the project.

Conflicts of Interest: The authors declare no conflict of interest.

\section{References}

1. Rosenboom, V.; Blagg, K. Disconnected from Higher Education: How Geography and Internet Speed Limit Access to Higher Education; Urban Institute: Washington, DC, USA, 2018.

2. Hightree, J.; Kliskey, A.; Higginsb, L.; Alessa, L.; Laninga, T.; Barrett, J. Themes in community resilience: A meta-synthesis of 16 years of Idaho Community Reviews. Community Dev. 2018, 49, 65-82. [CrossRef]

3. Schmitt-Wilson, S.; Downey, J.A.; Beck, A.E. Rural educational attainment: The importance of context. J. Res. Rural Educ. 2018, 33, $1-14$.

4. Corbett, M. Rural futures: Development, aspirations, mobilities, place, and education. Peabody J. Educ. 2016, 91, $270-282$. [CrossRef]

5. Snow College. Farm Management Education Increasing True Sustainability of Utah Farms and Ranches. 2015. Available online: https:/ / snow.edu/news/2015/farm_management.html (accessed on 16 December 2020).

6. The University of Utah. Urban Ecology. Available online: https://advising.utah.edu/majors/quick-look/urban-ecology.php (accessed on 16 December 2020).

7. Brigham Young University. Environmental Science. Available online: https://lifesciences.byu.edu/programs/plant-wildlifesciences/environmental-science (accessed on 16 December 2020).

8. Allen, J.M.; Wright, S.; Cranston, N.; Watson, J.; Beswik, K.; Hay, H. Raising levels of school student engagement and retention in rural, regional and disadvantaged areas: Is it a lost cause? Int. J. Incl. Educ. 2017, 22, 409-425. [CrossRef]

9. Chenoweth, E.; Galliher, R.V. Factors influencing college aspirations of rural west Virginia high school students. J. Res. Rural Educ. 2004, 19, 1-14.

10. James, R. Participation disadvantage in Australian higher education: An analysis of some effects of geographical location and socioeconomic status. High. Educ. 2001, 42, 455-472. [CrossRef] 
11. Koricich, A.; Chen, X.; Hughes, R.P. Understanding the effects of rurality and socioeconomic status on college attendance and institutional choice in the United States. Rev. High. Educ. 2018, 41, 281-305. [CrossRef]

12. Means, D.R.; Clayton, A.B.; Conzelmann, J.G.; Baynes, P.; Umbach, P.D. Bounded aspirations: Rural, African American high school students and college access. Rev. High. Educ. 2016, 39, 543-569. [CrossRef]

13. Zarifa, D.; Hango, D.; Milian, R.P. Proximity, prosperity, and participation: Examining access to postsecondary education among youth in Canada's provincial north. Rural Sociol. 2016, 83, 270-314. [CrossRef]

14. Corbett, M. I'm going to make sure I'm ready before I leave: The complexity of educational and mobility decision-making in a Canadian coastal community. J. Rural Stud. 2013, 32, 275-282. [CrossRef]

15. Corbett, M.; Forsey, M. Rural youth out-migration and education: Challenges to aspirations discourse in mobile modernity. Discourses Stud. Cult. Politics Educ. 2017, 38, 429-444. [CrossRef]

16. Farrugia, D. The mobility imperative for rural youth: The structural, symbolic and non-representational dimensions rural youth mobilities. J. Youth Stud. 2016, 19, 836-851. [CrossRef]

17. McLaughlin, D.K.; Shoff, C.M.; Demi, M.A. Influence of perceptions of current and future community on residential aspirations of rural youth. Rural Sociol. 2014, 79, 453-477. [CrossRef]

18. Abbott-Chapman, J.; Johnston, R.; Jetson, T. Rural belonging, place attachment, and youth educational mobility: Rural parents' views. Rural Soc. 2014, 23, 296-310. [CrossRef]

19. Byun, S.; Meece, J.L.; Irvin, M.J.; Hutchins, B.C. The role of social capital in educational aspirations of rural youth. Rural Sociol. 2012, 77, 355-379. [CrossRef] [PubMed]

20. Rosvall, P.; Ronnlund, M.; Johansson, M. Young people's career choices in Swedish rural contexts: Schools' social codes, migration and resources. J. Rural Stud. 2018, 60, 43-51. [CrossRef]

21. Leavy, J.; Smith, S. Future farmers: Youth aspirations, expectations and life choices. Future Agric. Discuss. Pap. 2010, 13, 1-15.

22. Byun, S.; Meece, J.L.; Agger, C.A. Predictors of college attendance patterns of rural youth. Res. High. Educ. 2017, 58, 817-842. [CrossRef]

23. McGrath, D.J.; Swisher, R.R.; Elder, G.H., Jr.; Conger, R.D. Breaking new ground: Diverse routes to college in rural America. Rural Sociol. 2001, 66, 244-267. [CrossRef]

24. Jukkala, A.M.; Henly, S.J.; Lindeke, L.L. Rural perceptions of continuing professional education. J. Contin. Educ. Nurs. 2008, 39, 555-563. [CrossRef]

25. Hillman, N. Place Matters: A Closer Look at Education Deserts; Third Way: Washington, DC, USA, 2019.

26. Kim, A. Make Rural America's "Higher Education Deserts" Bloom. In New Ideas for a Do-Something Congress; No. 5; Progressive Policy Institute: Washington, DC, USA, 2019.

27. Hillman, N.; Weichman, T. Education Deserts: The Continued Significance of "Place" in the Twenty-First Century. In Viewpoints: Voices from the Field; American Council on Education: Washington, DC, USA, 2016.

28. Turley, R.N.L. College proximity: Mapping access to opportunities. Sociol. Educ. 2009, 82, 126-146. [CrossRef]

29. Long, M.C.; Kennedy, A. Optimal Spatial Distribution of Colleges; Working Paper; Association for Public Policy Analysis and Management: Washington, DC, USA, 2015.

30. Brown, R.B.; Xu, X.; Barfield, M.A.; King, B.G. Community experience and the conceptual distinctness of rural community attachment and satisfaction: A measurement model. Res. Community Sociol. 2000, 10, 427-446.

31. Cope, M.R.; Flaherty, J.; Young, K.D.; Brown, R.B. Olympic boomtown: The social impacts of a one-time mega-event in Utah's Heber valley. Sociol. Spectr. 2015, 35, 136-160. [CrossRef]

32. Crowe, J. Community attachment and satisfaction: The role of a community's social network structure. J. Community Psychol. 2010, 38, 622-644. [CrossRef]

33. Filkins, R.; Allen, J.C.; Cordes, S. Predicting community satisfaction among rural residents: An integrative model. Rural Sociol. 2000, 65, 72-86. [CrossRef]

34. Goudy, W.J. Community attachment in a rural region. Rural Sociol. 1990, 55, 178-198. [CrossRef]

35. Rojek, D.G.; Clemente, F.; Summers, G.F. Community satisfaction: A study of contentment with local services. Rural Sociol. 1975, 40, 177-192.

36. McKnight, M.; Gibbs, B.; Sanders, S.S.; Cope, M.R.; Jackson, J.E.; Park, P.N. Small towns and urban centers: The relationship of distance and population size to community satisfaction. Community Dev. 2019, 50, 389-405. [CrossRef]

37. Campbell, A.; Converse, P.E.; Rodgers, W.L. The Quality of American Life; Russell Sage: New York, NY, USA, 1976.

38. Fleming, M.J.; Grace, D.M. Increasing participation of rural and regional students in higher education. J. High. Educ. Policy Manag. 2014, 36, 483-495. [CrossRef]

39. Liano, P.; Chang, H.; Wang, J.; Horng, T. Do rural students really perform worse than urban students do? Empirical evidence from a university entrance program in Taiwan. Rural Sociol. 2013, 78, 109-131.

40. Prescott, B.T. Predicaments of public institutions in rural settings. Chang. Mag. High. Learn. 2019, 51, 29-33. [CrossRef]

41. Beamer, L.; Steinbaum, M. Unequal and Uneven: The Geography of Higher Education Access. Phenomenal World. 2019. Available online: https:/ / phenomenalworld.org/analysis/geography-of-higher-ed (accessed on 4 December 2020).

42. Utah State University. Utah State University Statewide Campuses. 2020. Available online: https://statewide.usu.edu/ (accessed on 16 December 2020). 
43. Chronicle Staff. How Low Graduation Rates Camouflage Student Success at Community Colleges. Chronicle of Higher Education. 2020. Available online: https://www.chronicle.com/article/how-low-graduation-rates-camouflage-student-successat-community-colleges/?bc_nonce=16xn8q85y8v6uowmesrdg\&cid=reg_wall_signup (accessed on 16 December 2020).

44. Dillman, D.A.; Smyth, J.D.; Chrsitian, L.M. Internet, Mail, and Mixed Method Surveys: The Tailored Design Method; John Wiley: Hoboken, NJ, USA, 2009.

45. Brown, R.B. Rural community satisfaction and attachment in mass consumer society. Rural Sociol. 1993, 64, 188-196.

46. Marans, R.W.; Rogers, W. Toward an Understanding of Community Satisfaction. In Metropolitan American in Contemporary Perspective; Hawley, A., Rock, V., Eds.; Sage Publications: Thousand Oaks, CA, USA, 1975; pp. $299-352$.

47. Biden-Harris Campaign. The Biden Plan for Education Beyond High School. 2020. Available online: https://joebiden.com/ beyondhs / (accessed on 16 December 2020).

48. Li, C.; Lalani, F. The COVID-19 Pandemic Has Changed Education Forever: This Is How. World Economic Forum. 2020. Available online: https:/ / www.weforum.org/agenda/2020/04/coronavirus-education-global-covid19-online-digital-learning/ (accessed on 16 December 2020).

49. KSL News. One Utah College Is Projected to Have Lower Enrollment This Fall. What Is It Doing to Reverse That Trajectory? Available online: https:/ / www.ksl.com/article/50245837/one-utah-college-is-projected-to-have-lower-enrollment-this-fallwhat-is-it-doing-to-reverse-that-trajectory (accessed on 20 September 2020).

50. Farrington, J.; Farrington, C. Rural accessibility, social inclusion and social justice: Towards conceptualization. J. Transp. Geogr. 2005, 13, 1-12. [CrossRef] 